\title{
Cultural History, Science Studies, and Global Economy: New and Future Approaches
}

While the concept of a 'global economy' becomes more and more central in current debates, the history of such a conception of economy has hardly been investigated. Since when has the economy been perceived as a global issue? What ethical values were related to it, and what "epistemic virtues" (Daston and Galison 2007) were related to economics as a discipline dealing with global issues? What institutions and networks contributed to shaping the conception of the global economy? These and other questions should become the subject of a cultural history of the global economy. With a few exceptions, the perspectives of cultural history, science studies, and the history of knowledge are largely missing or at least underrepresented in economic history, where scholars have mostly taken the categories of economics for granted, basing their research upon these categories instead of examining their historicity (Dejung et al. 2011). However, other approaches are possible and, in part, they are already an emerging reality. As Michel Callon poignantly expressed it in an interview with Michel Ferrary: "Si l'économie-chose existe, c'est parce qu'elle a été performée par l'économiediscipline: 'no economy without economics!'” (Callon and Ferrary 2006). In the following pages, I will attempt to sketch these new approaches, and point to possible foci for future research and new ways of understanding the history of the economy and economics. At the same time, I will exemplify one possible approach through an analysis of discourses on the global economy between the second half of the nineteenth century and the first half of the twentieth century. ${ }^{1}$

An entangled history of knowledge of the global economy should approach economics as a scientific discipline not through its own categories, but through a discourse-analytical approach that allows taking a critical distance from the concepts of classical economic theory, and questioning their universal validity, thus historicizing economics as a science in the same way that classical categories within the humanities are increasingly historicized. ${ }^{2}$ In recent years, some schol-

1 I would like to thank my colleague in Siegen and former GCSC member, Katharina KreuderSonnen, for critically reading my paper.

2 On questioning the universality of the categories of the humanities, see Bachmann-Medick 2014; for discourse analysis applied to economy and economics, see the contributions in DiazBone 2015; on the history of discourses on the relationship between economy and politics in the twentieth century, see Scholl 2015. 
ars in the fields of history, sociology, science studies, and cultural studies have not only unveiled practices and conceptions in the economic sphere as being culturally determined (Berghoff and Vogel 2004), but also, and most importantly, have argued that the categories and methods of the discipline of economics play a key role in shaping economic processes themselves (Callon 1998, 2007; Knorr-Cetina and Preda 2005; Speich Chassé 2013). Among historians, Dejung, Dommann, and Speich Chassé (2014) have attempted to question the assumption that 'the economy' be a given rather than the product of historical transformations, negotiations, and shifts of meaning. They pled for an analysis of the relations between economy and economics on the one hand, and ethics, religion, and politics on the other hand, which should uncover their reciprocal intertwinement. Other historians have done research on the practices and techniques of economic knowledge production (e.g. Tooze 2001; Schneider 2013).

In this paper I would like to highlight emerging approaches to the history of economy and economics, as well as to suggest new ones. As I explained above, I will concretize one of these possible new approaches through a short analysis of discourses on the global economy. Thus, my aim is to uncover the historicity of the 'global economy' not by studying the development of economic processes, but by questioning the very understanding of these processes and the development of economics as a discipline being concerned with global economic processes. Like Monika Dommann argues with regard to legal history in her book on the history of copyright, Autoren und Apparate (2014), I maintain that economic history should also be approached with the methods of cultural history and the history of knowledge (see Speich Chassé and Gugerli 2012). The suggested approach is inspired by research in the humanities (Bod et al. 2014; in particular Daston 2014); by what Michel Foucault has initiated through his archeology of knowledge especially in the fields of medicine, psychiatry, and systems of punishment (Foucault 1969); as well as by what the history of science and the actor-network-theory have achieved in the history of the natural sciences and technology (Lenoir 1997; Mitchell 2005; Latour 2005).

The approach I exemplify seeks both to deconstruct the discourses on global economy and to reconstruct the networks of experts who contributed in spreading conceptions of world economy. "Travelling concepts" (Neumann and Nünning 2012; Bachmann-Medick 2014) between both disciplinary and national borders constitute a key theoretical approach for such an entangled history of economics, which should be both interdisciplinary and transnational. This approach implies a broadening of the future study of culture to a field, economics, whose laws are often considered to be universal and independent from cultural variances. At the same time, it potentially allows for interactions between historical disciplines on the one hand, and sociological and economic disciplines on the other hand, 
joining their efforts in the examination of the self-understanding of economics as a discipline and finally questioning its very categories.

The sources I will analyze are not limited to scientific publications, but include non-scientific publications that were influenced by, and themselves possibly influenced, scientific discourse. ${ }^{3}$ I do not adhere to an internalist conception of science, and therefore I do not think that considering economics as an abstract sphere isolated from other disciplines or from popularizing and political discourses would do justice to the breadth of the dynamics of knowledge circulation.

The time between 1850 and 1945 is of particular interest for my questions, which include: how did the term 'global economy' originate and spread? What contexts and constellations favored its multiplication and stabilization? What shifts in its meaning and what processes of translation were involved? To address this, I will indicate a few case studies as well as possible answers to these questions.

\section{The Emergence of the Concept of Global Economy}

In the following pages, I will describe a concrete example of a discourseanalytical approach to the emergence of discourses on world economy. That is: applying discourse analysis to some sources on the 'global economy' dating approximately from 1850 to 1945, I argue that discourses on the global economy (not 'global trade' or 'global commerce') emerged in this period of time. In fact, a bibliographic search based on library catalogues or databases will show that the term 'global economy,' in its variants of 'world economy,' 'Weltwirtschaft' or 'Weltökonomie,' 'wereld economie,' 'économie mondiale' and 'economia mondiale,' is nearly impossible to find before $1850 .{ }^{4}$ There are isolated examples from the 1830s, a few more since the 1850s, and the frequency always increases until the twentieth century, when the term becomes omnipresent after the 1940s.

The following examples show that, around 1870, discourses on world economy started to spread among economists. In a book on American Political Economy dating from 1870, the author, the American Francis Bowen (1811-1890),

3 On the circulation of scientific knowledge even beyond the scientific or academic sphere, and back, see Fleck 1980.

4 See Karlsruher Virtueller Katalog, https://kvk.bibliothek.kit.edu; Anno, Volltextsuche in Zeitungen und Zeitschriften, Österreichische Nationalbibliothek, Suche: 'Weltwirtschaft,' http://anno. onb.ac.at/anno-suche\#searchMode=simple\&query=weltwirtschaft\&resultMode=list\&from=1: the search in ANNO gives the following results for each of the following time periods: 1867-1881 (7 results); 1882-1897 (46); 1898-1912 (455); 1913-1928 (3.259); 1929-1945 (2.988) [both last accessed: June 2016]. 
Professor at Harvard, criticizes Malthusian theories appealing to a greater dimension in the economic space, namely "world's economy":

\begin{abstract}
We can now see with sufficient distinctiveness the two great facts which afford a complete refutation of Malthusianism. The first is, that the limit of Population, in any country whatever, is not the number of people which the soil of that country alone will supply with food, but the number which the surface of the whole earth is capable of feeding; and it is a matter of demonstration, that this limit cannot even be approached for many centuries. The inability of England alone, or of Ireland alone, to supply her teeming population with food, is a fact of no more importance in the world's economy, than the inability of the city of London alone to supply her two millions of people with farm-produce from her own soil. London taxes all the counties of England for her sustenance; England taxes all the countries of the world for her sustenance; - I cannot see any difference between the two cases.
\end{abstract}

(Bowen 1870, 140, emphasis mine, italics in the original)

As we can see from this justification of colonial politics, expansionism and economical exploitation of the resources of other continents entailed thinking in a global scale, and it is in this context that talking about a national economy was not sufficient any longer.

In a German source from 1873, an article by the political economist Karl Knies (1821-1898), a representative of the historical school, the "global economy" ("die Weltwirtschaft, als ein großes Ganzes betrachtet") is opposed to isolated national economy ("eine von allen übrigen Völkern isolierte Volkswirtschaft”), thus also implying that the global economy represents a higher dimension, to which national economies are subordinated (Knies 1873, 307, italics in the original). However, 'world economy' was already present also beyond the scientific discourse. In the same year, the international exhibition in Vienna also spoke of a global economy as opposed to national economy, and its journal pled for a transition from a national to an all-encompassing global economy:

However, we should not lose sight of at least one characteristic of our times at the World Exhibition in Vienna: the transformation of national economies [Volkswirtschaften] into the global economy [Weltwirtschaft]. International conventions and boards should be established as basis for later diplomatic or political action.

(Anonymous 1873, 2; my translation) $^{5}$

From this example we can induce that international exhibitions, such as the one that was organized in Vienna in 1873, were places where the world economy was actively performed, and its very conception was actively shaped and spread. In

5 "Zumal aber einen Charakterzug der Zeit dürfen wir bei der Wiener Weltausstellung nicht aus dem Auge verlieren: den Uebergang der Volkswirtschaften in die Weltwirtschaft. Internationale Einigungen und Berathungen sollen als Grundlage für eine spätere diplomatische oder politische Action geschaffen werden.” 
the following decades, the higher dimension of a world economy acquired an increasing important role in economic theory, and already in 1905 we can find that a congress was held in Belgium on the "world's economic development" (“Congrès international d'expansion économique mondiale") (Anonymous 1905). A search in the abovementioned databases lets us also see that the frequency of the term increased from 1919, after World War I, and especially in the 1930's and 40's. In particular, we can observe a stabilization of the term in scientific language, as well as in handbooks: in 1919 we can find, for instance, a publication called Die Weltwirtschaft der Fettstoffe (Fitzner 1919), in 1916 one called U-Boot und Weltwirtschaft (Thielemann 1916); some books asked about "the place" of particular nations in "world economy" (Arndt 1908; Rathgen 1911; Schumacher 1917), other books opposed the global economy to national economy ("Volkswirtschaft" or "Nationalwirtschaft") (Dietzel 1900; Oppenheimer 1915).

Besides that, the proceedings of conferences relating to economic and political matters, organized by supranational entities such as the League of Nations, show that the term was becoming more and more present in the political sphere between the 1920s and 1930s (see League of Nations 1927). This is confirmed by publications such as L'économie mondiale et la Société des Nations (Hantos 1930). A further important step in the institutionalization of the study of the 'global economy' was the foundation of the journal Weltwirtschaftliches Archiv in Kiel in 1913 (still existing as Review of World Economics), edited by Bernhard Harms. The Weltwirtschaftliches Archiv presented itself as a scientific journal with the aim of studying the history and the functioning of world economy, an issue that, as the editor maintained, was highly important but had not received the due attention until that moment (Harms 1913, 1-36). Bernhard Harms founded the "Königliches Institut für Seeverkehr und Weltwirtschaft" at the Christian-Albrechts-Universität in Kiel in 1914, another step in the institutionalization of the 'world economy.' As we will see later on, its importance went beyond national borders and contributed in spreading the concept in the international scientific discourse; in fact, the German concept of 'Weltwirtschaft' and, in particular, the translation of (the titles of) some works by German scholars publishing in the journal Weltwirtschaftliches Archiv, played a significant role in the European scenario. Another example is the "Hamburgisches Welt-Wirtschafts-Archiv," founded in 1908 and being part of the Hamburgisches Kolonialinstitut (Thilenius 1920); as we can see, even in this case the idea of global economy went hand-in-hand with colonialism.

6 On scientific disciplines and institutions, in particular on the natural sciences, see Lenoir 1992 and 1997, as well as Stichweh 1994. On economics as a scientific discipline: Schneider 2013, Hesse 2010, and Mitchell 2005. 


\section{Socialism and the Concept of World Economy}

In the 1920s, socialist and communist economic theories were an important factor of the increased popularity of concepts of global economy. Above all, they brought the term outside the scientific discourse, as we can see from the communist newspaper Die Rote Fahne, published in socialist Vienna of the 1920s. Here, 'world economy' was conceived in opposition to 'national economy':

For years, the principle of global economy has been competing with the one of national economy. The longer the struggle went on, the clearer it was that the idea of the global economy, of the increasingly more intimate economic connection of all countries, is the stronger one.

(Anonymous 1920, 2; my translation) ${ }^{7}$

According to these lines, the global economy, where all countries are economically bound to each other, had proved to be "stronger" than the principle of a national economy, and had triumphed over it. As we can see from the following passage, capitalist economy was perceived as being bound to older, national economic models, and the war was conceived as a break in global economic relations:

Short before the beginning of the war, capitalist economy was showing its weakest side. Almost everywhere there was a quite heavy crisis, unemployment was remarkable. At this point, the war administered the heaviest blow to the principle of the global economy. Great nations broke all relations with one another and wanted to support only the resources and the laws of development [economic development, but the analogy with Darwinism and the natural sciences is obvious, L.M.] of their own country. From then on there was no global economy for the Central Powers anymore, but only an economy, which did not overcome the national borders. For years, the capitalists considered the decline of the global economy as a fruitful result. Instead of the economic relations on the world market, military [relations] on the battlefield emerged.

(Anonymous 1920, 2; my translation) $^{8}$

7 "Jahrzehntelang kämpfte das Prinzip der Weltwirtschaft mit dem der nationalen Wirtschaft. Je länger der Kampf währte, desto offenbarer wurde es, daß der Gedanke der Weltwirtschaft, der immer innigeren ökonomischen Verknüpfung aller Länder, der stärkere sei.”

8 "Kurz vor Ausbruch des Krieges zeigte die kapitalistische Weltwirtschaft ihre schwächste Seite. Beinahe überall herrschte eine ziemlich schwere Krise, die Arbeitslosigkeit war bedeutend. In diesem Augenblicke wurde dem Prinzip der Weltwirtschaft der schwerste Schlag durch den Krieg versetzt. Große Staaten lösten alle wirtschaftlichen Beziehungen zueinander und wollten nur die Hilfsquellen und die Entwicklungsgesetze des eigenen Landes zur Geltung kommen lassen. Von nun an gab es für die Mittelmächte keine Weltwirtschaft mehr, sondern nur eine Wirtschaft, die über die Staatsgrenzen nicht hinausreichte. Jahrelang galt für die Kapitalisten der Verfall der Weltwirtschaft als fruchtbringendes Ergebnis. An Stelle der wirtschaftlichen Beziehungen auf dem Weltmarkte traten die militärischen auf dem Schlachtfelde.” 
Capitalism took advantage from the crisis of world economy, it is stated, substituting trade relations with military relations. Of course, communist and socialist papers were not the only that interpreted the war as interruption of global economic relations: in the Habsburg Monarchy of 1915, the Fremden Blatt encouraged the development of national economy, since the global economy had been destroyed by the war:

Since the global economy is destroyed, there are no international relations anymore, and we must strive with all our forces to nationalize our economy again [...].

(Wurm-Arnkreuz 1915, 4; my translation) ${ }^{9}$

The concept of the global economy can be found in the socialist discourse well before the 1920s, and constituted a topic of socialist congresses already in 1894: for instance, it was mentioned in the Protokoll des Internationalen Sozialistischen Arbeiterkongresses held in Zurich in $1894 .{ }^{10}$ In this case, the fact that the world's economy was accompanied by a condition of constant warfare was identified as one of the contradictions of capitalism.

The importance of the 'world economy' for communist and socialist discourses was well known, and the term was recognized as being directly connected with these currents of thought. For instance, an Italian scientific publication already described 'world economy' as an economic category typical for communism as early as 1876 (Ciccone 1876, 178). ${ }^{11}$ At that time, the expression was rare to find in other Italian-language contexts. Socialism from Genesis to Revelation (1892), by Franklin M. Sprague, also mentioned "world economy" in relation to socialist economy (Sprague 1892, 404). Socialist newspapers thus possibly played a key role in spreading the discourse on world economy beyond the scientific domain of economics. As Ludwik Fleck maintained with regard to knowledge circulation in the natural sciences (Werner and Zittel 2011, 23), economic knowledge was transferred beyond the scientific sphere and became exoteric knowledge (which then eventually might have come back into the esoteric sphere of economics, having been transformed and adapted).

9 "Weil die Weltwirtschaft zusammengebrochen ist, gibt es keine internationalen Beziehungen mehr, und wir müssen mit allen Kräften bemüht sein, unsere Wirtschaft wieder zu nationalisieren [...]."

10 Protokoll des Internationalen Sozialistischen Arbeiterkongresses in der Tonhalle Zürich vom 6. bis 12. August 1893: "Nur das Proletariat hat ein Lebensinteresse, den Widersinn der heutigen Gesellschaft zu beseitigen: Weltwirtschaft - und ständige Kriegsgefahr [...],” 1894, 2.

11 Ciccone: “[...] economia pubblica, economia politica, cui aggiungono i comunisti una economia mondiale," 1876, 178. 


\section{Technology and Communication: Changing Representations of Global Space and Economy}

Focusing on the conception of space, we can ask how the idea of a global economic space was constructed, but also which economic processes were seen as influencing economy on a global scale. For instance, the first issue of the Weltwirtschaftliches Archiv contains an article on the Panama Canal (Stubmann 1913), as well as on the global significance of railways (Thieß 1913). It would also be interesting to explore the connection between technical innovations - especially infrastructures - and conceptions of global economy.

In fact, means of communication such as the telegraph and the telephone were understood as being deeply bound to the development of global economic relationships, as we can see from volume fifteen of the British Board of Trade Journal, which at the end of the nineteenth century stated: "The Americans were the first to realise the importance of telephony and to appreciate the part it was likely to play in the world's economy" (Commercial Department of the Board of Trade 1893, 264).

At the same time, means of transport and communication routes - and thus technical innovations in general - were also conceived as a way of fostering the 'world economy.' In the 1893 handbook Descriptive Economics: An Introduction to Economic Science, we can read:

Fast lines of steamships bring all parts of the globe into communication. They have facilities for transporting all products. The Suez canal went a long way toward furthering the world economy. A Nicaragua canal may sometime do even more.

(Bly 1893, 233)

Thus, we can infer that the growth of communication and transport routes, as well as technical innovations that allowed faster exchange of goods and opened up new trade relations, signified a change in the perception of space, and that these changes favored thinking of economy not as a national or colonial but as a global issue.

For this reason, the spatial turn (Bachmann-Medick 2016, 211-243) and the history of technology must also be considered central theoretical approaches for an entangled history of economy and economics, whereas questions of mobility (of persons as well as of objects) should be as important as the questions of knowledge transfer that I examine in the next section.

\section{Travelling Concepts in World Economy}

Finally, a possible research focus in the history of the global economy lies on transnational and interdisciplinary transfer: on knowledge transfer on the international 
level, on the one hand, and on conceptual transfer between disciplinary and social fields, on the other. Knowledge transfer can be analyzed through a comparison of economic journals from different countries, and by asking how their terminology and conception of world economy show reciprocal influences. Conceptual transfer could be highlighted through the analysis of metaphors and imageries from fields other than classical economic theory. In both cases, we can conceptualize these phenomena as 'travelling concepts' in the history of economics.

Interestingly, the translation of German book titles (though not necessarily of their contents) in the 1920s seems to have been important for the diffusion of the term 'économie mondiale' in French. ${ }^{12}$ However, even well before the founding of the Weltwirtschaftliches Archiv in Kiel, discourses on global economy were triggered by the translation of the German word 'Weltwirtschaft.' For example, in 1855 the Annali universali di statistica, published in Milan, displayed the term 'world economy' in Italian ('economia mondiale'), which at that time was still very rarely used, in the translation of a German title, System der Weltökonomie (Anonymous, 1855, 117-118). ${ }^{13}$ The use of the term in English was also influenced by German terminology: for instance, Kaufmann's Socialism (1874), declaredly "based on” Schäffle's book Kapitalismus und Socialismus (1870), uses the words "universal economy" with the meaning of world economy. It relates the concept to a series of negative values:

Over-little as well as over-much state help is undesirable. The individual citizen now-a-days is so intimately connected with and dependent on the movements of the great social body, and with the progressive extension of the economic circle all over the world (comprehending not only individuals but whole nations), every isolated domestic economy is drawn so completely into the general vortex of universal economy, or at least the economy of nations, that it becomes the undoubted duty of the society to protect its component members against those contingencies which arise from such a complicated system of economy.

(Kaufmann 1874, 284)

As we can see, the text reflects the German opposition of "Weltwirtschaft" and "isolierte Volkswirtschaft" discussed above. In this quotation, however, the global economy was presented as dangerous and complicated. Moreover, in this

12 Brocard 1929, 25, quoted Bernhard Harms, Économie nationale et économie mondiale, 1924; von Tyrka, Problèmes d'économie mondiale des états industriels modernes, 1916; Nachimsen, Économie mondiale avant et après la guerre, 1926. The expression 'économie mondiale' is rare to find in French titles in the same period.

13 The title referred to is Winkelblech 1853, translated as: Ricerche sull'organizzazione del lavoro, o Sistema d'economia mondiale. 
publication, dating from the 1870s, the concept was projected onto other epochs, and it was understood as a typical feature of capitalism:

From times immemorial capitalism has maintained its place among other systems in the world's economy. It was the ruling principle in the commerce of the Phoenicians, the Italians, the German towns, long before slavery and feudalism ceased to dispute its pretension as the exclusive motor of society.

(Kaufmann 1874, 63)

In fact, communism and capitalism were identified as two different "modes of world's economy":

To return then to a public state communism, pure and simple, as the best mode of the world's economy, instead of simply purifying and further developing our present capitalistic forms, would be a lamentable step backwards.

(Kaufmann 1874, 247)

In this passage, the author suggested to modify, improve, and "purify" capitalism, opposing "public state communism."

The projection of the concept of global economy onto other historical periods can also be conceived as a form of conceptual transfer or translation. This began around 1915, and developed especially after the 1930s and 1940s, when the concept was stabilized in scientific language and enjoyed increasing usage also beyond the scientific field. English imperial and colonial economy, for example, was now described as "Englische Weltwirtschaft," an expression that was not used before the twentieth century (Predöhl 1949, 65-66). Thus, discourses on the global economy, whose beginnings I have briefly sketched, can be better understood through the analytical category of "travelling concepts" or "concepts in translation” (Bachmann-Medick 2014, 119-136). In this way, we can relativize and historicize concepts that have often been considered as being obvious and universally valid - their universality being granted by economic 'laws.'

\section{Conclusion: Approaches to Deconstructing Economics}

In this article, I have pointed to a new way of looking at economics and its concepts and categories. Furthermore, I have tried to exemplify this through a brief analysis of discourses on global economy and how they were translated from and into different languages and contexts. This is, of course, only a short and exemplary case study, and there is still much work to do in order to uncover the making of the global economy and to deconstruct the categories of economic science. Such a process of deconstruction of economics implies several challenges, but at the 
same time new and interesting results. First, it means questioning the universality of economic laws, as has been done with the categories of the humanities and the natural sciences, thereby also paving the way for a "cross-categorical translation" (Chakrabarty) of even too "obvious” economic terms (see Bachmann-Medick 2012, 33-35). Second, it allows a deeper understanding of the ethical and epistemic values attributed to economic concepts and ideas, following the methods that historians of science have applied to the history of the natural sciences (Daston and Galison 2007) and of the humanities (Daston 2014). Third, it results in studying the multiple processes of translation and adaptation of the categories of economic science. Last, but not least, science studies applied to the history of economy and economics entail analyzing the construction of scientificity, of 'the market' and of 'the economy' in and through the discipline of economics, which can be both visual (e.g. through diagrams or other visualizations of statistical data) and textual (Latour 2006 [1986], 279).

In order to point to how one could go even further than discourse analysis, I have suggested studying the perception of global economic processes in its interaction with the perception of new media, means of transport and communication, and mobility (see Callon and Ferrary 2006). In this sense, a cultural history of the global economy cannot be conceived without history of science and history of knowledge, science and technology studies (STS), and media studies. However, it would only then be truly interdisciplinary when engaging in a dialogue with literary studies (see the contribution by Tom Clucas in this volume as well as Joseph Vogl 2002). Its dimensions should go beyond Eurocentric approaches and consider the translational, transnational, global, and (post-) colonial aspects of the understanding of economy and the development of economics as a discipline. Since this implies that researchers can understand the languages and have a deep knowledge of the history of geographic areas other than those traditionally belonging to the 'West,' area studies are indeed much needed for such new approaches to an entangled history of economics. Finally, those who dare to go beyond the traditionally established borders attributed not only to written sources, but also to the textual as a form of publishing research results, should follow Peter Galison's (2014) and Andressa Schröder's (in this volume) hints and allow filmmaking and art to enter the domain of scientific research. As Peter Galison has argued in his 2014 article and shown through movies he has (co-)directed, documentaries can represent a complementary way of doing history of science. I would suggest that the same is true for economic processes and the understanding of economics, where historians and sociologists could only profit from cooperation with visual artists and filmmakers. It is a question of materiality, too: indeed, what could be a better means than film to make the voices of the (subaltern) people heard, the technological and natural 
soundscape listened to, and the interplay of nature, humans, animals, technology, and economic interests seen? For instance, in the documentary Sonic Sea (2016), dealing with man-made ocean noise and related environmental problems, the film directors Michelle Dougherty and Daniel Hinerfeld succeed in this aim. I thus conclude encouraging more openness to non-traditional, non-textual forms of expression from the side of historians, not only as sources and as means of knowledge dissemination, but also as epistemic tools, as ways of doing research and producing knowledge they should seriously confront.

\section{References}

Anonymous. “Bibliografia: Rassegna di opere straniere.” Annali universali di statistica 5.14

(1855): $116-120$.

Anonymous. Internationale Ausstellungszeitung. Beilage der Neuen Freien Presse zu Nr. 3140 (21 May 1873).

Anonymous. Protokoll des Internationalen Sozialistischen Arbeiterkongresses in der Tonhalle Zürich vom 6. bis 12. August 1893. Zurich: Buchhandlung des Schweiz. Grütlivereins, 1894.

Anonymous. Congrès international d'expansion économique mondiale tenu à Mons du 24 au 28 septembre 1905 sous le haut patronage Sa Majesté le roi Leopold II. et du gouvernement Belge. 8 vols. Bruxelles: Hayez, 1905.

Anonymous. "Weltwirtschaft und Revolution." Die Rote Fahne 3.279 (14 April 1920).

Arndt, Paul. Deutschlands Stellung in der Weltwirtschaft. Leipzig: Teubner, 1908.

Bachmann-Medick, Doris. "Translation: A Concept and Model for the Study of Culture." Travelling Concepts for the Study of Culture. Eds. Birgit Neumann and Ansgar Nünning. Berlin/New York: De Gruyter, 2012. 23-43.

Bachmann-Medick, Doris. "From Hybridity to Translation: Reflections on Travelling Concepts." The Trans/National Study of Culture: A Translational Perspective. Ed. Doris Bachmann-Medick. Berlin/Boston: De Gruyter, 2014. 119-136.

Bachmann-Medick, Doris. Cultural Turns: New Orientations in the Study of Culture. Berlin/ Boston: De Gruyter, 2016.

Berghoff, Hartmut, and Jakob Vogel, eds. Wirtschaftsgeschichte als Kulturgeschichte. Dimensionen eines Perspektivenwechsels. Frankfurt a.M./New York: Campus, 2004.

Bly, Myron T. Descriptive Economics: An Introduction to Economic Science for Use in Academies, High and Normal Schools, and Business Colleges. New York/Cincinnati: American Book Co., 1893.

Bod, Rens, Jaap Maat, and Thijs Weststeijn, eds. The Making of the Humanities. Vol. 3: The Modern Humanities. Amsterdam: Amsterdam University Press, 2014.

Bowen, Francis. American Political Economy: Including Strictures on the Management of the Currency and the Finances Since 1861, with a Chart Showing the Fluctuations in the Price of Gold. New York: Scribner \& Co., 1870.

Brocard, Lucien. Principes d'économie nationale et international. Vol. 1. Paris: Sirey, 1929. Callon, Michel, ed. The Laws of the Markets. Oxford/Malden, MA: Blackwell, 1998. 
Callon, Michel, ed. Market Devices. Oxford/Malden, MA: Blackwell, 2007.

Callon, Michel, and Michel Ferrary. "Les réseaux sociaux à l'aune de la théorie de l'acteur-réseau.” Sociologies pratiques 13.2 (2006): 37-44. DOI 10.3917/sopr.013.0037 [accessed: 25 November 2019].

Ciccone, Antonio. "La nuova scuola economica tedesca detta socialismo della cattedra e la sua introduzione in Italia." Atti dell'Accademia di scienze morali e politiche di Napoli 14 (1876): 1-256.

Commercial Department of the Board of Trade. Board of Trade Journal 15 (1893).

Daston, Lorraine. "Objectivity and Impartiality: Epistemic Virtues in the Humanities."

The Modern Humanities: The Making of the Humanities. Vol. 3. Eds. Rens Bod, Jaap Maat, and Thijs Weststeijn. Amsterdam: Amsterdam University Press, 2014. 27-42.

Daston, Lorraine, and Peter L. Galison. Objectivity. New York: Zone Books, 2007.

Dejung, Christof, Monika Dommann, and Daniel Speich Chassé. "Wissen und Wirtschaften." WerkstattGeschichte 58 (2011): 3-7.

Dejung, Christof, Monika Dommann, and Daniel Speich Chassé, eds. Auf der Suche nach der Ökonomie. Historische Annäherungen. Tübingen: Mohr Siebeck, 2014.

Diaz-Bone, Rainer, ed. Diskurs und Ökonomie. Diskursanalytische Perspektiven auf Märkte und Organisationen. 2nd ed. Wiesbaden: Springer VS, 2015.

Dietzel, Heinrich. Weltwirtschaft und Volkswirtschaft. Dresden: Zahn und Jaensch, 1900.

Dommann, Monika. Autoren und Apparate. Die Geschichte des Copyrights im Medienwandel. Frankfurt a.M.: Fischer, 2014.

Dougherty, Michelle, and Daniel Hinerfeld (film directors). Sonic Sea. 2016.

Fitzner, Rudolf. Die Weltwirtschaft der Fettstoffe. 8 vols. Berlin: Heymann, 1919.

Fleck, Ludwik. Entstehung und Entwicklung einer wissenschaftlichen Tatsache. Einführung in die Lehre vom Denkstil und Denkkollektiv. Eds. Lothar Schäfer and Thomas Schnelle. Frankfurt a.M.: Suhrkamp, 1980.

Foucault, Michel. L’Archéologie du Savoir. Paris: Gallimard, 1969.

Galison, Peter L. "Meanings of Scientific Unity: The Law, the Orchestra, the Pyramid, Quilt, and Ring." Pursuing the Unity of Science: Ideology and Scientific Practice from the Great War to the Cold War. Eds. Harmke Kamminga and Geert Somsen. Burlington, VT: Ashgate, 2016. 12-29.

Hantos, Elemér. L'économie mondiale et la Société des Nations. Paris: Marcel Giard, 1930.

Harms, Bernhard. "Weltwirtschaft und Weltwirtschaftslehre." Weltwirtschaftliches Archiv 1.1 (1913): 1-36.

Hesse, Jan-Otmar. Die Wirtschaft als Wissenschaft. Bundesdeutsche Volkswirtschaftslehre zwischen Weltkrieg und Ölpreiskrise. Frankfurt a.M.: Campus Verlag, 2010.

Kaufmann, Moritz. Socialism: Its Nature, Its Dangers, and Its Remedies Considered, based on the German work Kapitalismus und Socialismus, by Dr. A.E.F. Schäffle. London: Henry S. King \& Co., 1874.

Knies, Karl. Geld und Kredit. Vol. 1. Berlin: Weidmann, 1873.

Knorr-Cetina, Karin, and Alex Preda, eds. The Sociology of Financial Markets. Oxford: Oxford University Press, 2005.

Latour, Bruno. Reassembling the Social: An Introduction to Actor-Network-Theory. Oxford: Oxford University Press, 2005.

Latour, Bruno. "Drawing Things Together. Die Macht der unveränderlich mobilen Elemente." ANThology. Ein einführendes Handbuch zur Akteur-Netzwerk-Theorie. Eds. Andréa Bellinger and David J. Krieger. Bielefeld: transcript, 2006 [1986]. 259-307. 
League of Nations. Journal de la Conférence économique internationale, Genève 1927. Genève:

A. Kundig, 1927.

Lenoir, Timothy. Politik im Tempel der Wissenschaft. Forschung und Machtausübung im deutschen Kaiserreich. Frankfurt a.M.: Campus, 1992.

Lenoir, Timothy. Instituting Science: The Cultural Production of Scientific Disciplines. Stanford: Stanford University Press, 1997.

Mitchell, Timothy. "Economists and the Economy in the Twentieth Century." The Politics of Method in the Human Sciences: Positivism and Its Epistemological Others. Ed. George Steinmetz. Durham, NC: Duke University Press, 2005. 126-142.

Neumann, Birgit, and Ansgar Nünning, eds. Travelling Concepts for the Study of Culture. Berlin/New York: De Gruyter, 2012.

Oppenheimer, Franz. Weltwirtschaft und Nationalwirtschaft. Berlin: Fischer, 1915.

Predöhl, Andreas. Aussenwirtschaft. Weltwirtschaft, Handelspolitik und Währungspolitik. Göttingen: Vandenhoeck \& Ruprecht, 1949.

Rathgen, Karl. Die Japaner in der Weltwirtschaft. 2nd ed. Leipzig: Teubner, 1911.

Schäffle, Albert. Kapitalismus und Socialismus. Tübingen: Laupp, 1870.

Schneider, Michael C. Wissensproduktion im Staat: Das königlich preußische statistische Bureau 1860-1914. Frankfurt a.M.: Campus Verlag, 2013.

Scholl, Stefan. Begrenzte Abhängigkeit. 'Wirtschaft' und 'Politik' im 20. Jahrhundert. Frankfurt a.M./New York: Campus, 2015.

Schumacher, Hermann Albert. Belgiens Stellung in der Weltwirtschaft. Leipzig: Hirzel, 1917.

Speich Chassé, Daniel, and David Gugerli. “Wissensgeschichte. Eine Standortbestimmung.” Traverse. Zeitschrift für Geschichte/Revue d'histoire 19.1 (2012): 85-100.

Speich Chassé, Daniel. Die Erfindung des Bruttosozialprodukts. Globale Ungleichheit in der Wissensgeschichte der Ökonomie. Göttingen: Vandenhoek \& Ruprecht, 2013.

Sprague, Franklin Monroe. Socialism from Genesis to Revelation. Boston: Lee and Shepard, 1892.

Stichweh, Rudolf. Wissenschaft, Universität, Professionen. Soziologische Analysen. Frankfurt a.M.: Suhrkamp, 1994.

Stubmann, Peter. “Panamakanal und Weltwirtschaft.” Weltwirtschaftliches Archiv 1.1 (1913): 286-309.

Thielemann, Walter. U-Boot und Weltwirtschaft. Das Wirtschaftsleben im Gesamtunterricht der Arbeitsschule. Leipzig/Prague/Vienna: Haase, 1916.

Thieß, Karl. “Die Weltspur der Eisenbahnen.” Weltwirtschaftliches Archiv 1.1 (1913): 325-341.

Thilenius, Georg Christian. "Hamburgisches Kolonialinstitut.” Deutsches Kolonial-Lexikon. Vol. 2. Ed. Heinrich Schnee. Leipzig: Quelle \& Meyer, 1920. 12.

Tooze, J. Adam. Statistics and the German State, 1900-1945: The Making of Modern Economic Knowledge. Cambridge/New York: Cambridge University Press, 2001.

Vogl, Joseph. Kalkül und Leidenschaft. Poetik des ökonomischen Menschen. Zurich/Berlin: Diaphanes, 2002.

Werner, Sylwia, and Claus Zittel, eds. Ludwik Fleck. Denkstile und Tatsachen. Gesammelte Schriften und Zeugnisse. Berlin: Suhrkamp, 2011. 9-38.

Winkelblech, Karl Georg. Untersuchungen über die Organisation der Arbeit oder System der Weltökonomie. Kassel: Appel, 1853.

Wurm-Arnkreuz, k.k. Oberbaurat v. "Der Krieg und die Kulturträger." Fremden-Blatt 69.17 (1915): 4. 